\title{
Strategies for improving production performance of probiotic Pediococcus acidilactici viable cell by overcoming lactic acid inhibition
}

\author{
Majdiah Othman ${ }^{1}$, Arbakariya B. Ariff ${ }^{1,2}$, Helmi Wasoh ${ }^{1,2}$, Mohd Rizal Kapri $^{2}$ and Murni Halim ${ }^{1,2^{*}}$ (D)
}

\begin{abstract}
Lactic acid bacteria are industrially important microorganisms recognized for fermentative ability mostly in their probiotic benefits as well as lactic acid production for various applications. Fermentation conditions such as concentration of initial glucose in the culture, concentration of lactic acid accumulated in the culture, types of $\mathrm{pH}$ control strategy, types of aeration mode and different agitation speed had influenced the cultivation performance of batch fermentation of Pediococcus acidilactici. The maximum viable cell concentration obtained in constant fed-batch fermentation at a feeding rate of $0.015 \mathrm{~L} / \mathrm{h}$ was 6.1 times higher with 1.6 times reduction in lactic acid accumulation compared to batch fermentation. Anion exchange resin, IRA 67 was found to have the highest selectivity towards lactic acid compared to other components studied. Fed-batch fermentation of P. acidilactici coupled with lactic acid removal system using IRA 67 resin showed 55.5 and 9.1 times of improvement in maximum viable cell concentration compared to fermentation without resin for batch and fed-batch mode respectively. The improvement of the $P$. acidilactici growth in the constant fed-batch fermentation indicated the use of minimal and simple process control equipment is an effective approach for reducing by-product inhibition. Further improvement in the cultivation performance of $P$. acidilactici in fed-bath fermentation with in situ addition of anion-exchange resin significantly helped to enhance the growth of $P$. acidilactici by reducing the inhibitory effect of lactic acid and thus increasing probiotic production.
\end{abstract}

Keywords: Lactic acid bacteria, Lactic acid, Extractive fermentation, Fed-batch fermentation, End-product inhibition, Anion exchange resin

\section{Introduction}

Lactic acid bacteria (LAB) have recently attracted greater attention for industrial use due to their microorganisms beneficial to human or animals and probiotic properties (Hwang et al. 2011). Pediococcus acidilactici is one of the probiotics which commonly found as one of the normal flora of alimentary tract, oral cavity gastro intestinal tract and has been widely used in the food industry (Halim et al. 2017). Foods that contain probiotic in an appropriate amount are beneficial to human for instance

\footnotetext{
*Correspondence: murnihalim@upm.edu.my

${ }^{1}$ Department of Bioprocess Technology, Faculty of Biotechnology and Biomolecular Sciences, Universiti Putra Malaysia, 43400 Serdang, Selangor, Malaysia

Full list of author information is available at the end of the article
}

in enhancing immune system, antibiotics production and prevention of mucosal infection in children. Probiotic products are recommended to contain at least $10^{7}$ living microorganisms per $\mathrm{mL}$ or per $\mathrm{g}$ (Elsayed et al. 2014). In addition, foods and tablets consist of LAB have been manufactured and consumed clinically. Therefore, it is necessary for a suitable commercial product to contain a high density of viable cells for efficient effects (Cui et al. 2016).

High cell density during fermentation is important in order to achieve targeted biomass, lactic acid and other metabolites productivity. Nonetheless, the conditions of the fermentation medium such as $\mathrm{pH}$, temperature, substrates and by-products are the main influences on the microbial growth and product formation (Boon et al. 
2007). Generally, conducive biochemical and biophysical conditions are important for bacteria to grow and express normal metabolic activities. Biophysical conditions such as temperature, $\mathrm{pH}$, redox potential, water activity and the presence of inhibitory compounds gave a broad range of variations among LAB strains. A suitable biochemical condition for LAB to grow can be obtained from nutrients provided by the culture media (Hayek and Ibrahim 2013).

Batch, fed-batch and continuous are three fermentation modes commonly used for biomass production in microbial fermentation. Among these, batch fermentation is identified to be the most frequently used for fermentation process due to the simplicity of the process where no substrates components are required to be added during the fermentation process except neutralizing agents for pH controlling (Abdel-Rahman et al. 2013). The closed system of batch fermentation minimize the risk of contamination and in turn produce a high lactic acid concentration as compared to other fermentation modes (Hofvendahl and Hahn-Hägerdal 2000). However, batch fermentation has the drawbacks of producing low cell concentrations mainly due to the limited nutrient levels (Abdel-Rahman et al. 2013) and the LAB culture often suffers from substrate and product inhibitions in which contributes to the low productivity (Hujanen et al. 2001).

Fed-batch fermentation is normally used in order to avoid substrate-level inhibition in microbial fermentation (Bai et al. 2003). In comparison, batch and fed-batch fermentations may produce higher lactic acid concentrations than a continuous fermentation. Often, this is due to the complete consumption of substrates available in the batch and fed-batch fermentations, whereas there are always remaining residual concentrations of substrates in the continuous fermentation (Hofvendahl and Hahn-Hägerdal 2000; Abdel-Rahman et al. 2013). In-situ removal of lactic acid from fermentation broth is another interesting strategy to reduce lactic acid product inhibition in the fermentation of LAB (Cui et al. 2016; Garret et al. 2015; Jianlong et al. 1994). Nonetheless, most of the studies on the extractive fermentation of lactic acid using anion exchange resin are focusing on the improvement of lactic acid production instead of cell biomass (Boonmee et al. 2016). Limited literature is therefore available on the combination of both lactic acid extractive fermentation using anion exchange resin and fed-batch fermentation aiming at the improvement of LAB biomass.

The purpose of this study was to investigate the effects of fermentation conditions on the growth of batch fermentation of $P$. acidilactici and to improve its cultivation performance through the application of constant fed-batch fermentation in $2 \mathrm{~L}$ stirred tank bioreactor. Fermentation conditions such as concentration of initial glucose in the culture, concentration of lactic acid accumulated in the culture, types of $\mathrm{pH}$ control strategy, types of aeration mode and different agitation speed were studied on batch fermentation of $P$. acidilactici. Whilst for the constant fed-batch fermentation, different feeding rates were used to study the effects of feeding rate on viable cells production and lactic acid accumulated from cultivation of $P$. acidilactici. Lactic acid extractive fermentation using anion exchange resin, IRA 67 was conducted on fed-batch fermentation of $P$. acidilactici to further improve its growth. The results of this study may provide several innovative strategies for improvement of biomass production in LAB fermentation.

\section{Materials and methods}

\section{Microorganism, culture maintenance and inoculum preparation}

Pediococcus acidilactici DSM 20238 used in this study was obtained from Bioprocessing and Biomanufacturing Research Center, Universiti Putra Malaysia which was initially purchased from DSMZ-German Collection of Microorganisms and Cell Cultures. This strain was used throughout the study due to its capability to produce lactic acid as a sole product. De Man, Rogosa and Sharpe (MRS) medium was used for growing of $P$. acidilactici strain and for maintenance of the culture. The MRS medium was purchased from Merck Millipore, Germany. The compositions of MRS medium in deionized water $(\mathrm{g} / \mathrm{L})$ were: peptone from casein 10.0, meat extract 8.0, yeast extract $4.0, \mathrm{D}(+)$ glucose 20.0 , di-potassium hydrogen phosphate 2.0, Tween 801.0 , di-ammonium hydrogen citrate 2.0 , sodium acetate 5.0 , magnesium sulfate 0.2 , and manganese sulfate 0.04 . The strain was stored at $-20{ }^{\circ} \mathrm{C}$ in $15 \%(\mathrm{v} / \mathrm{v})$ glycerol. The strain was inoculated into $50 \mathrm{~mL}$ MRS broth in $250 \mathrm{~mL}$ non-baffled Erlenmeyer flasks and incubated in an incubator shaker (Certomat ${ }^{\circledR}$ BS-1 Braun, Germany) at $37{ }^{\circ} \mathrm{C}$ and agitated at $200 \mathrm{rpm}$ for $24 \mathrm{~h}$. The bacterial cells were harvested by centrifugation (Eppendorf Centrifuge $5810 \mathrm{R}$ ) at 10,000 rpm for $10 \mathrm{~min}$. The bacterial pellets were resuspended in $15 \%$ (v/v) glycerol and stored at $-20{ }^{\circ} \mathrm{C}$ for maintenance. The $15 \%(\mathrm{v} / \mathrm{v})$ glycerol was prepared by mixing with distilled water and autoclaving at $121{ }^{\circ} \mathrm{C}$ and 15 psi for 15 min for sterilization purpose. Inoculum was prepared by growing one loopful of $P$. acidilactici culture from MRS agar plate in $250 \mathrm{~mL}$ non-baffled Erlenmeyer flasks containing $50 \mathrm{~mL}$ MRS medium. The strain was incubated at $37{ }^{\circ} \mathrm{C}$ in an orbital shaker, which was agitated at $200 \mathrm{rpm}$ for $10 \mathrm{~h}$ to be used as inoculum in fermentation process.

\section{Batch fermentation}

For preliminary experiments, the fermentations were done in $500 \mathrm{~mL}$ non-baffled Erlenmeyer flasks containing 
$100 \mathrm{~mL}$ MRS medium with composition as previously described. Different glucose concentrations $(0-20 \mathrm{~g} / \mathrm{L})$ were used in MRS medium to study the effect of glucose consumption and lactic acid accumulated in the culture on growth of $P$. acidilactici. Different lactic acid concentrations $(5-15 \mathrm{~g} / \mathrm{L})$ were added into the culture during exponential phase of the bacterial growth to investigate the lactic acid inhibition towards the growth of $P$. acidilactici. Batch cultivation was carried out in a $2 \mathrm{~L}$ stirred tank bioreactor (BIOSTAT, B. Braun Biotech International, $\mathrm{GmbH}$, Germany). The bioreactor vessel was made of borosilicate glass and the top-plate of the bioreactor was made of stainless steel. The bioreactor was equipped with a thermostat jacket system for temperature controlling within the bioreactor by means of an external double wall with a circulation pump. The bioreactor was connected with temperature, $\mathrm{pH}$ and dissolved oxygen monitoring and control system. $\mathrm{pH}$ of the culture was controlled by addition of sodium hydroxide $(\mathrm{NaOH})$ or hydrochloric acid $(\mathrm{HCl})$ accordingly. Alkali, acid and feed medium were added into the culture using peristaltic pumps. Antifoam was not added into the bioreactor since foaming was not a problem during fermentation. The bioreactor was equipped with a six blade Rushton turbine for mixing system. Batch cultivations were carried out in a $2 \mathrm{~L}$ stirred tank bioreactor containing $1 \mathrm{~L}$ of MRS medium. The culture in bioreactor was also inoculated with $10 \%(\mathrm{v} / \mathrm{v})$ inoculum similar to the shake flask culture. The fermentations were carried out under facultative condition, agitated at $300 \mathrm{rpm}$, at $37^{\circ} \mathrm{C}$ and the $\mathrm{pH}$ was not controlled but monitored throughout the fermentation, unless stated otherwise. The effect of fermentation conditions with and without $\mathrm{pH}$ control on the fermentation performance of $P$. acidilactici was studied by running the fermentation at both non-regulated $\mathrm{pH}$ and regulated $\mathrm{pH}$ value of $5.7 \pm 0.2$ (equivalent to the initial $\mathrm{pH}$ value of MRS broth). The initial $\mathrm{pH}$ values of these two conditions were adjusted by $1 \mathrm{M} \mathrm{NaOH}$ or $\mathrm{HCl}$. Due to the lactic acid production during fermentation of $P$. acidilactici, the $\mathrm{pH}$ was maintained with $1 \mathrm{M} \mathrm{NaOH}$ during the fermentation for $\mathrm{pH}$ control condition. The effect of aeration on the fermentation performance of $P$. acidilactici was studied by running the fermentation with and without air supply. Due to the facultative characteristic of $P$. acidilactici, two different modes of aeration were selected to study the effect of aeration on the growth of $P$. acidilactici. For the anaerobic condition, the fermentation was done by sparging the medium with nitrogen gas at $0.1 \mathrm{vvm}(0.15 \mathrm{~L} / \mathrm{min})$ until the dissolved oxygen level reached zero value prior to fermentation. Nitrogen gas was stopped once the culture was inoculated, and the fermentation was allowed to proceed without aeration. For the facultative condition, the fermentation was done by sparging the medium with oxygen gas at $0.1 \mathrm{vvm}(0.15 \mathrm{~L} /$ min) until the dissolved oxygen level achieved 100\% prior to fermentation. Oxygen gas was stopped once the culture was inoculated, then the fermentation proceeded without aeration. Finally, the effect of different mixing rate on the fermentation performance of $P$. acidilactici, was evaluated at three different mixing speeds of 200 , 300 and $400 \mathrm{rpm}$.

\section{Constant fed-batch fermentation}

Constant fed-batch fermentations were conducted in a $2 \mathrm{~L}$ stirred tank bioreactor at three different feeding rates of $0.008,0.015$ and $0.03 \mathrm{~L} / \mathrm{h}$. Basically the constant fedbatch fermentations were conducted in two phases. In the initial phase, $P$. acidilactici was cultured in a batch fermentation mode with a working volume of $0.9 \mathrm{~L}$ until glucose was exhausted. Once the glucose was exhausted, which occurred approximately at $12 \mathrm{~h}$ of the initial batch fermentation, the second phase of the fermentation was started with fed-batch mode. During the second phase, the fed-batch was initiated with $100 \mathrm{~mL}$ of concentrated glucose $(10 \mathrm{~g} / \mathrm{L})$ was being added continuously into the bioreactor at a constant feeding rate to make up the total volume of $1 \mathrm{~L}$.

\section{Anion-exchange resin selectivity towards lactic acid}

A weak base anion-exchange resin (Amberlite IRA 67, Cat. No. 476633) was used in this study for in situ removal of lactic acid from the culture. The resin was purchased from Sigma, Germany and was sterilized using ultraviolet radiation before used in the experiments. The tubes were centrifuged at $10,000 \mathrm{rpm}$ for $10 \mathrm{~min}$ to separate resins from the solution to be used for determination of remaining lactic acid in the solution. Resin can be reused by washing the resin with distilled water followed by regenerating with $4 \% \mathrm{NaOH}$ to elute the lactic acid from the resin at an ambient temperature. The theory of the Langmuir isotherm model assumes adsorption only occurs at specific homogeneous adsorbent sites and no further adsorption can take place at the same site once a lactic acid molecule adsorbs on the site (Gao et al. 2010). The specific uptake capacity of lactic acid (q) for the Langmuir isotherm model was determined by using Eq. 1:

$$
q=\frac{(C i-C e q)}{X}
$$

From Eq. 1, q (g of lactic acid/g of biosorbent) is the specific uptake capacity of lactic acid, $\mathrm{C}_{\mathrm{i}}(\mathrm{g} / \mathrm{L})$ is the initial concentration of lactic acid, $\mathrm{C}_{\mathrm{eq}}(\mathrm{g} / \mathrm{L})$ is the equilibrium concentration of lactic acid and $\mathrm{X}(\mathrm{g} / \mathrm{L})$ is the concentration of biosorbent in solution. Sorption equilibrium studies for a single component present in MRS media 
(glucose and sodium acetate) and organic acid other than lactic acid (acetic acid) were conducted to study the selectivity of IRA 67 anion-exchange resin towards these components as compared to lactic acid. IRA 67 resin $(10 \mathrm{~g} / \mathrm{L})$ were added into $15 \mathrm{~mL}$ falcon tubes with each separately contained $10 \mathrm{~mL}$ glucose, sodium acetate and acetic acid with initial concentration of $5 \mathrm{~g} / \mathrm{L}$. The tubes were agitated at $200 \mathrm{rpm}$ on a shaker for $24 \mathrm{~h}$ until the sorption reached equilibrium. The adsorption capacity of IRA 67 resin for glucose, sodium acetate and acetic acid was calculated using Eq. 1 by determining the remaining of these components in the solution. The experiments were done in triplicate.

\section{Constant fed-batch fermentation coupled with lactic acid extractive fermentation using anion-exchange resin}

The cultivation performance of $P$. acidilactici in the constant fed-batch fermentation coupled with extractive fermentation using the condition of dispersed anion-exchange resin were conducted at feeding rate of $0.015 \mathrm{~L} / \mathrm{h}$. The sterilized an anion-exchange resin was aseptically added $(10 \mathrm{~g} / \mathrm{L})$ into the culture during inoculation. Fermentation culture was centrifuged at $10,000 \mathrm{rpm}$ for $10 \mathrm{~min}$ to separate resins from the culture to be used for further application. Resin can be reused by washing and regenerating as mentioned in the previous section.

\section{Analytical methods}

Throughout the fermentations, $5 \mathrm{~mL}$ of culture samples were withdrawn at time intervals for analysis. Cell growth was determined using colony forming unit (CFU) (Ming et al. 2016). Samples were serially diluted $\left(10^{3}-10^{10}\right)$ with $0.9 \%(\mathrm{w} / \mathrm{v})$ sterile saline water $(\mathrm{NaCI})$ and plated onto MRS agar plate. Samples were incubated for $24 \mathrm{~h}$ at $37^{\circ} \mathrm{C}$ and were analyzed for CFU/mL by calculating the total number of colonies on a plate and multiplied by the dilution involved. The supernatant was separated from the broth by centrifugation at $10,000 \mathrm{rpm}$ for $10 \mathrm{~min}$ to be used for glucose and lactic acid determination. The concentrations of glucose and lactic acid were determined by using reverse-phase high performance liquid chromatography (RP-HPLC) (Waters 2695, Separations Module and Waters 2410, Refractive Index Detector). The RP-HPLC analysis was done using a shodex SH-1011 column $(7 \mu \mathrm{m}$, $8 \mathrm{~mm} \times 300 \mathrm{~mm}$ ) connected with shodex SH-G guard column $(7 \mu \mathrm{m}, 6 \times 50 \mathrm{~mm})$. The mobile phase solvent used was $5 \mathrm{mM}$ sulphuric acid, the temperature was maintained at $60{ }^{\circ} \mathrm{C}$ and the flow rate was $1.0 \mathrm{~mL} / \mathrm{min}$. Empower software was used for data processing.

\section{Statistical analysis}

The experiments data were statistically analysed by using MS Office Excel 2010 and SPSS software Version 21. The data represents averages of at least three replicates. The results were represented as mean value \pm standard deviation. Unpaired $T$ test and one way analysis of variance (One way ANOVA) were used to determine the significance among treatment means. Significance was declared at $\mathrm{P}<0.05$.

\section{Results}

Effect of glucose concentration on growth of $P$. acidilactici and lactic acid accumulation

Varying the initial glucose concentration from 0 to $20 \mathrm{~g} / \mathrm{L}$ in batch fermentation was found to affect the growth of P. acidilactici (Fig. 1). Increased in initial glucose concentration from 0 to $10 \mathrm{~g} / \mathrm{L}$ increased viable cell concentration of $P$. acidilactici (from $9.4 \times 10^{8}$ to $1.4 \times 10^{10} \mathrm{cfu}$ / $\mathrm{mL}$ ) by about 14.9 times whilst at glucose concentration of above $10-20 \mathrm{~g} / \mathrm{L}$ viable cell concentration of $P$. acidilactici was reduced by about 1.4 times (from $1.4 \times 10^{10}$ to $1.0 \times 10^{10} \mathrm{cfu} / \mathrm{mL}$ ). Viable cell concentration obtained and lactic acid accumulated at the end of the fermentation were significantly different $(\mathrm{P}<0.05)$ at different initial glucose concentrations studied. Although the growth of $P$. acidilactici was slightly reduced as glucose concentration was increased from above 10 to $20 \mathrm{~g} / \mathrm{L}$, however, lactic acid accumulation and glucose consumption were still increased from 5.91 to $8.71 \mathrm{~g} / \mathrm{L}$ and 8.77 to $13.59 \mathrm{~g} / \mathrm{L}$, respectively.

\section{Effect of lactic acid concentration on growth inhibition of $P$. acidilactici}

Different lactic acid concentrations $(0,5,10$ and $15 \mathrm{~g} / \mathrm{L})$ were added to the culture at exponential phase of growth $(8 \mathrm{~h})$ to study the effect of lactic acid on viability of $P$. acidilactici after exponential phase. Lactic acid was added at exponential phase instead of at the beginning of the fermentation due to the failure of cells to grow in highly acidic condition during initial or lag phase (data not shown). As tabulated in Table 1, final viable cell concentration obtained at the end of the fermentation was significantly different $(P<0.05)$ at different lactic acid concentrations added. Final viable cell concentration of $P$. acidilactici was decreased proportionally with increased of lactic acid concentration. The final viable cell concentration reduced from $9.1 \times 10^{9}$ to $8.2 \times 10^{7} \mathrm{cfu} / \mathrm{mL}$ when $5 \mathrm{~g} / \mathrm{L}$ of lactic acid was added. The final viable cell concentration was then further reduced to $8.4 \times 10^{4} \mathrm{cfu} / \mathrm{mL}$ when $10 \mathrm{~g} / \mathrm{L}$ of lactic acid was added and no cells were survived when $15 \mathrm{~g} / \mathrm{L}$ of lactic acid was added to the culture. 


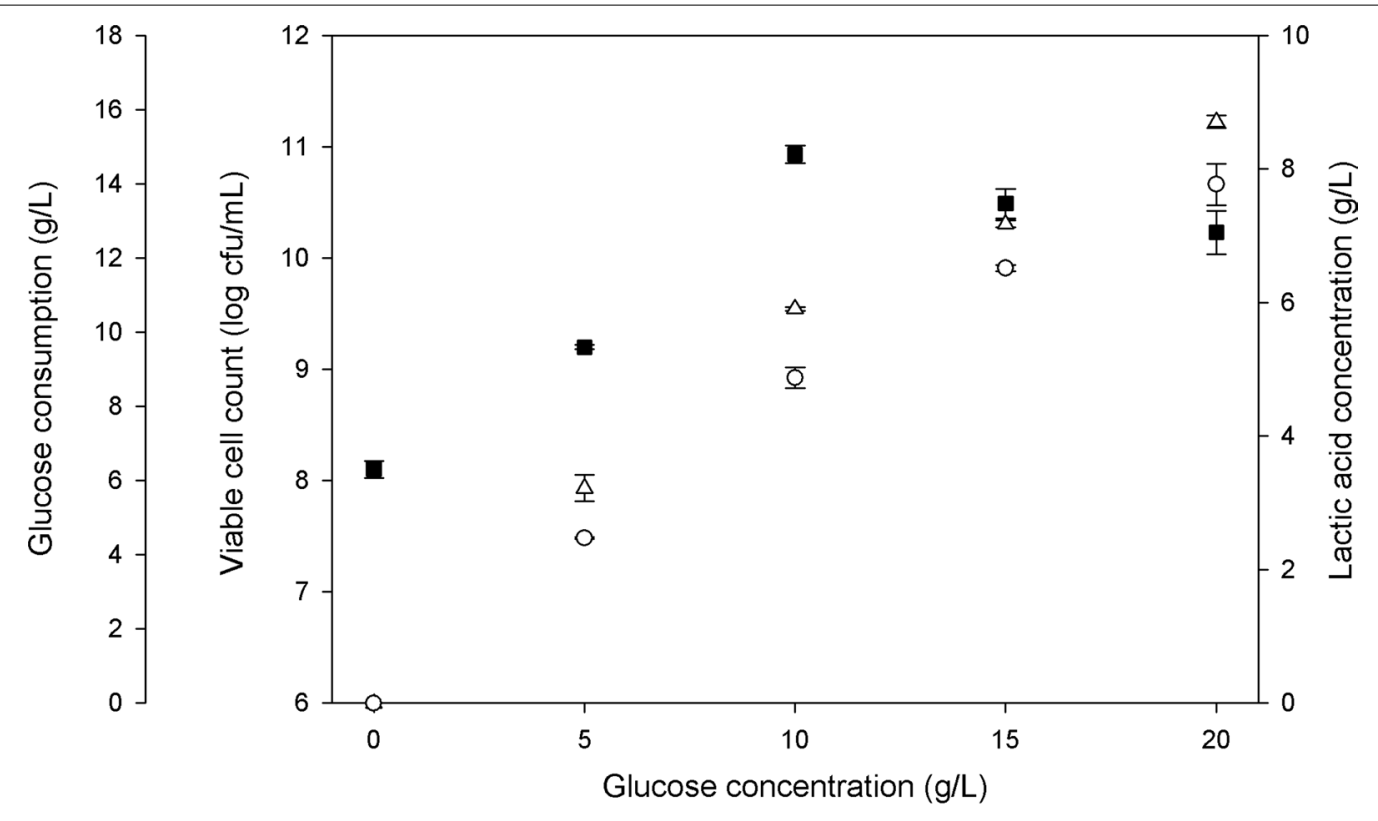

- Viable cell count $(\log \mathrm{cfu} / \mathrm{mL})$
$\Delta \quad$ Lactic acid concentration $(\mathrm{g} / \mathrm{L})$
$0 \quad$ Glucose consumption $(\mathrm{g} / \mathrm{L})$

Fig. 1 Effect of glucose concentration on growth of P. acidilactici and lactic acid accumulation. The fermentation was conducted in $500 \mathrm{~mL}$ shake flask, at $200 \mathrm{rpm}$. The data are the average of triplicate experiments. The error bars represent the standard deviations about the mean $(\mathrm{n}=3)$

Table 1 Viability of $P$. acidilactici in $500 \mathrm{~mL}$ shake flask at different lactic acid concentrations

\begin{tabular}{lll}
\hline Lactic acid added (g/L) & Lactic acid accumulated $(\mathbf{g} / \mathbf{L})^{\mathbf{e}}$ & Final viable cell concentration $(\mathbf{c f u} / \mathbf{m L})$ \\
\hline 0 & $6.47 \pm 0.23^{\mathrm{d}}$ & $9.1 \times 10^{9} \pm 0.12^{\mathrm{a}}$ \\
5 & $11.33 \pm 0.20^{\mathrm{c}}$ & $8.2 \times 10^{7} \pm 0.35^{\mathrm{b}}$ \\
10 & $16.52 \pm 0.18^{\mathrm{b}}$ & $8.4 \times 10^{4} \pm 0.27^{\mathrm{c}}$ \\
15 & $21.89 \pm 0.14^{\mathrm{a}}$ & 0.0 \\
\hline
\end{tabular}

The results presented are the average of triplicate experiments and are expressed as mean \pm standard deviation

$a, b, c, d$ Mean values in the same row with different superscripts are significantly different from each other $(P<0.05)$

e Lactic acid accumulated is the total of lactic acid added to the culture and lactic acid produced from fermentation

Effect of $\mathrm{pH}$ control strategy on growth of $P$. acidilactici in batch cultivation using $\mathbf{2} \mathrm{L}$ stirred tank bioreactor In order to study the inhibitory effect of $\mathrm{pH}$ reduction due to lactic acid production from fermentation of $P$. acidilactici on its growth, batch fermentations of $P$. acidilactici with and without $\mathrm{pH}$ control conditions were conducted. The time course of the fermentation is shown in Fig. 2 and the performance of the cultivation is summarized in Table 2 . In the culture without $\mathrm{pH}$ control condition, the maximum viable cell concentration $\left(1.5 \times 10^{12} \mathrm{cfu} /\right.$ $\mathrm{mL}$ ) was 8.3 times higher than the culture with $\mathrm{pH}$ control condition $\left(1.8 \times 10^{11} \mathrm{cfu} / \mathrm{mL}\right)$. Furthermore, viable cell yield and viable cell productivity obtained in the culture without $\mathrm{pH}$ control were also 8.9 times and 8.0 times respectively, higher than that obtained in the culture with $\mathrm{pH}$ control. Maximum viable cell concentration, viable cell yield and viable cell productivity obtained were significantly different $(P<0.05)$ at both with and without $\mathrm{pH}$ control conditions. These results hence proved that the addition of $\mathrm{NaOH}$ to control the $\mathrm{pH}$ was not effective in reducing end-product inhibition in fermentation of $P$. acidilactici. There were significant differences $(P<0.05)$ in lactic acid produced and lactic acid productivity for both types of cultures. Lactic acid produced in fermentation without $\mathrm{pH}$ control condition $(13.17 \mathrm{~g} / \mathrm{L})$ was 1.0 time higher compared to the fermentation with $\mathrm{pH}$ control condition $(12.72 \mathrm{~g} / \mathrm{L})$ and lactic acid productivity in fermentation without $\mathrm{pH}$ control condition $(0.54 \mathrm{~g} / \mathrm{L} \mathrm{h})$ 

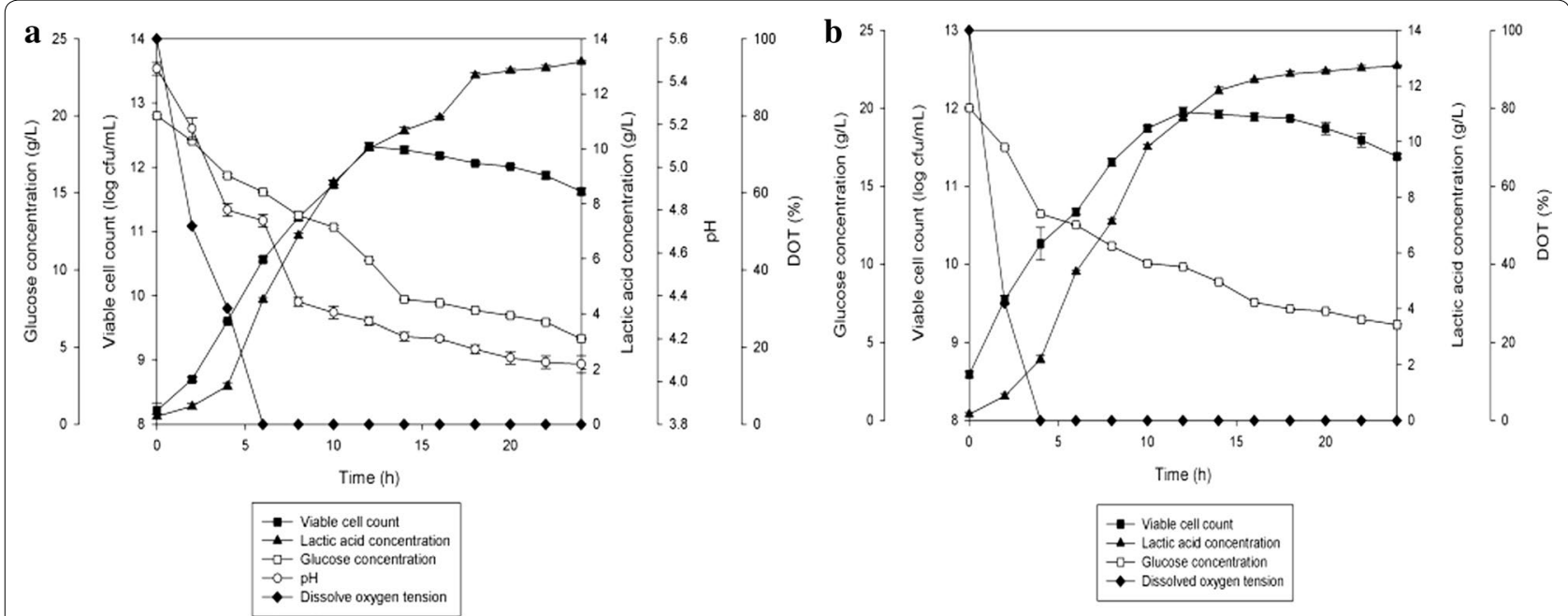

Fig. 2 The time course of batch fermentation of P. acidilactici in $2 \mathrm{~L}$ stirred tank bioreactor $\mathbf{a}$ without $\mathrm{pH}$ control, $\mathbf{b}$ with $\mathrm{pH}$ control at $\mathrm{pH}$ 5.7. The fermentation was conducted at $300 \mathrm{rpm}$. The error bars represent the standard deviations about the mean $(n=3)$

Table 2 Effect of culture pH on growth of $P$. acidilactici in batch fermentation using 2 L stirred tank bioreactor

\begin{tabular}{lll}
\hline Kinetic parameter & No pH control & pH 5.7 \\
\hline Maximum viable cell concentration (cfu/mL) & $1.5 \times 10^{12} \pm 0.17^{\mathrm{a}}$ & $1.8 \times 10^{11} \pm 0.24^{\mathrm{b}}$ \\
Time to reach maximum viable cell concentration (h) & $12^{\mathrm{a}}$ & $12^{\mathrm{a}}$ \\
Viable cell yield (cfu/g $\left.\mathrm{g}_{\text {Glucose }}\right)$ & $1.6 \times 10^{14} \pm 0.15^{\mathrm{a}}$ & $1.8 \times 10^{13} \pm 0.12^{\mathrm{b}}$ \\
Viable cell productivity (cfu/mL h) & $1.2 \times 10^{11} \pm 0.12^{\mathrm{a}}$ & $1.5 \times 10^{10} \pm 0.18^{\mathrm{b}}$ \\
Maximum lactic acid concentration $(\mathrm{g} / \mathrm{L})$ & $13.17 \pm 0.08^{\mathrm{a}}$ & $12.72 \pm 0.1^{\mathrm{b}}$ \\
Lactic acid yield (g/g $\left.\mathrm{g}_{\text {Glucose }}\right)$ & $0.90 \pm 0.05^{\mathrm{a}}$ & $0.90 \pm 0.06^{\mathrm{a}}$ \\
Lactic acid productivity $(\mathrm{g} / \mathrm{L}$ h) & $0.54 \pm 0.05^{\mathrm{a}}$ & $0.52 \pm 0.08^{\mathrm{b}}$
\end{tabular}

The results presented are the average of triplicate experiments and are expressed as mean \pm standard deviation

a,b Mean values in the same row with different superscripts are significantly different from each other $(P<0.05)$

was 1.03 times higher compared to the fermentation with $\mathrm{pH}$ control condition ( $0.52 \mathrm{~g} / \mathrm{L} \mathrm{h})$. Lactic acid accumulated was slightly lower in fermentation with $\mathrm{NaOH}$ addition due to lactic acid being neutralized. However, lactic acid yield was similar for both types of cultures $(0.90 \mathrm{~g} /$ $\left.\mathrm{g}_{\text {Glucose }}\right)$, showing no significant difference $(P<0.05)$ in lactic acid yield for both with and without $\mathrm{pH}$ control conditions.

\section{Effect of aeration on growth of $P$. acidilactici in batch cultivation using $2 \mathrm{~L}$ stirred tank bioreactor}

For facultative microorganisms such as P. acidilactici, facultative condition was shown to improve the cultivation performance of $P$. acidilactici compared to anaerobic condition (Fig. 3). As shown in Table 3, maximum viable cell concentration, viable cell yield and viable cell productivity obtained were slightly higher in facultative condition $\left(1.7 \times 10^{12} \mathrm{cfu} / \mathrm{mL}, 1.9 \times 10^{14} \mathrm{cfu} / \mathrm{g}_{\text {Glucose }}\right.$ and $1.4 \times 10^{11} \mathrm{cfu} / \mathrm{mL} \mathrm{h}$, respectively) compared to anaerobic condition $\left(1.2 \times 10^{11} \mathrm{cfu} / \mathrm{mL}, 1.3 \times 10^{13} \mathrm{cfu} / \mathrm{g}_{\text {Glucose }}\right.$ and
$9.9 \times 10^{9} \mathrm{cfu} / \mathrm{mL} \mathrm{h}$, respectively). Maximum viable cell concentration, viable cell yield and productivity obtained were significantly different $(P<0.05)$ at both facultative and anaerobic conditions. Similar to the results of maximum viable cell concentration, yield and productivity, the same trend was obtained for lactic acid production, yield and productivity, where the results were slightly higher in facultative condition $\left(12.98 \mathrm{~g} / \mathrm{L}, 0.91 \mathrm{~g} / \mathrm{g}_{\text {Glucose }}\right.$ and $0.53 \mathrm{~g} / \mathrm{L}$ h respectively) compared to anaerobic condition (11.32 $\mathrm{g} / \mathrm{L}, 0.86 \mathrm{~g} / \mathrm{g}_{\mathrm{Glucose}}$ and $0.46 \mathrm{~g} / \mathrm{L} \mathrm{h}$ respectively). There were significant differences $(P<0.05)$ in lactic acid production, yield and productivity obtained at both facultative and anaerobic fermentations.

\section{Effect of agitation speed on growth of $P$. acidilactici in batch cultivation using $2 \mathrm{~L}$ stirred tank bioreactor} The growth profiles for batch fermentation of $P$. acidilactici in $2 \mathrm{~L}$ stirred tank bioreactor at different agitation speeds are shown in Fig. 4. Increased in agitation speed from 200 to $300 \mathrm{rpm}$ showed improvement in maximum 

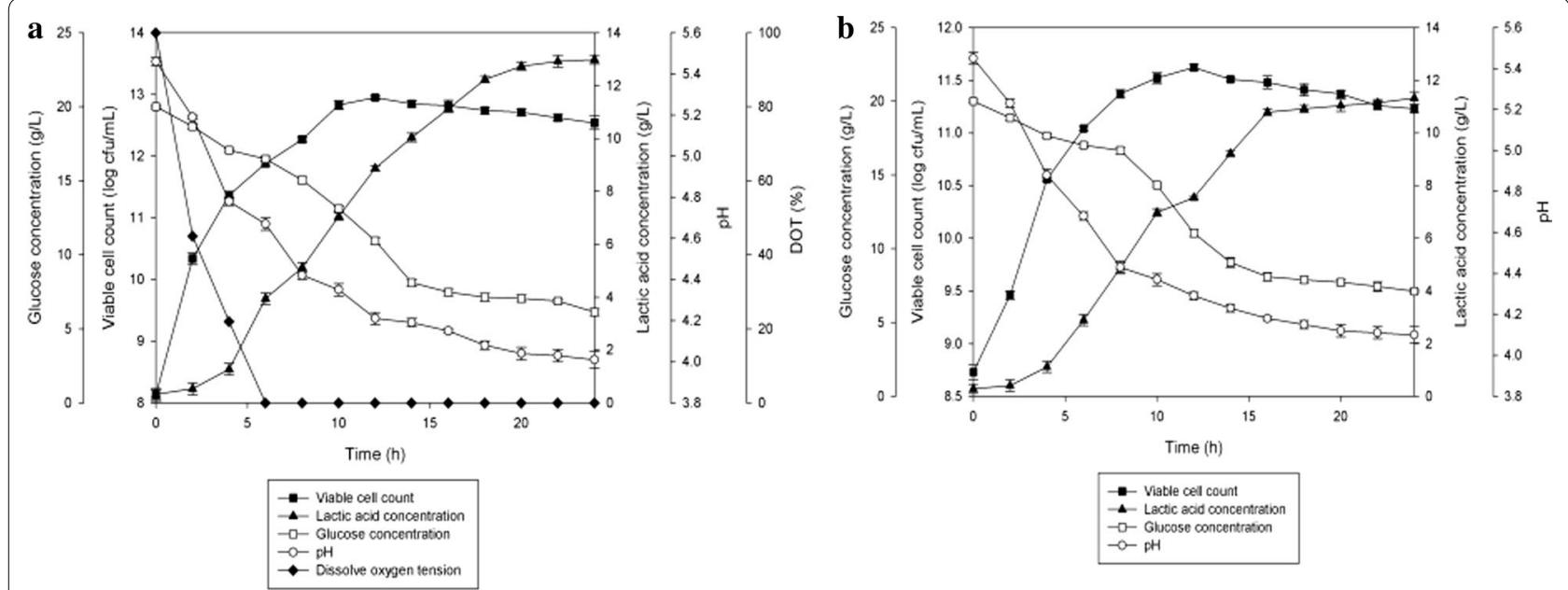

Fig. 3 The time course of batch fermentation of P. acidilactici in $2 \mathrm{~L}$ stirred tank bioreactor at condition of $\mathbf{a}$ facultative, $\mathbf{b}$ anaerobic. The fermentation was conducted at $300 \mathrm{rpm}$. The error bars represent the standard deviations about the mean $(n=3)$

Table 3 Effect of aeration on growth of $P$. acidilactici in batch fermentation using $\mathbf{2} L$ stirred tank bioreactor

\begin{tabular}{|c|c|c|}
\hline Kinetic parameter & Facultative & Anaerobic \\
\hline Maximum viable cell concentration (cfu/mL) & $1.7 \times 10^{12} \pm 0.13^{a}$ & $1.2 \times 10^{11} \pm 0.21^{b}$ \\
\hline Time to reach maximum viable cell concentration (h) & $12^{\mathrm{a}}$ & $12^{\mathrm{a}}$ \\
\hline Viable cell yield (cfu/g $\left.g_{\text {Glucose }}\right)$ & $1.9 \times 10^{14} \pm 0.12^{\mathrm{a}}$ & $1.3 \times 10^{13} \pm 0.17^{b}$ \\
\hline Viable cell productivity (cfu/mL h) & $1.4 \times 10^{11} \pm 0.1^{\mathrm{a}}$ & $9.9 \times 10^{9} \pm 0.13^{b}$ \\
\hline Maximum lactic acid concentration ( $g / L)$ & $12.98 \pm 0.21^{\mathrm{a}}$ & $11.32 \pm 0.23^{b}$ \\
\hline Lactic acid yield ( $\left.\mathrm{g} / \mathrm{g}_{\text {Glucose }}\right)$ & $0.91 \pm 0.18^{\mathrm{a}}$ & $0.86 \pm 0.21^{b}$ \\
\hline Lactic acid productivity ( $\mathrm{g} / \mathrm{L} \mathrm{h}$ ) & $0.53 \pm 0.14^{\mathrm{a}}$ & $0.46 \pm 0.17^{b}$ \\
\hline
\end{tabular}

The results presented are the average of triplicate experiments and are expressed as mean \pm standard deviation

a,b Mean values in the same row with different superscripts are significantly different from each other $(P<0.05)$

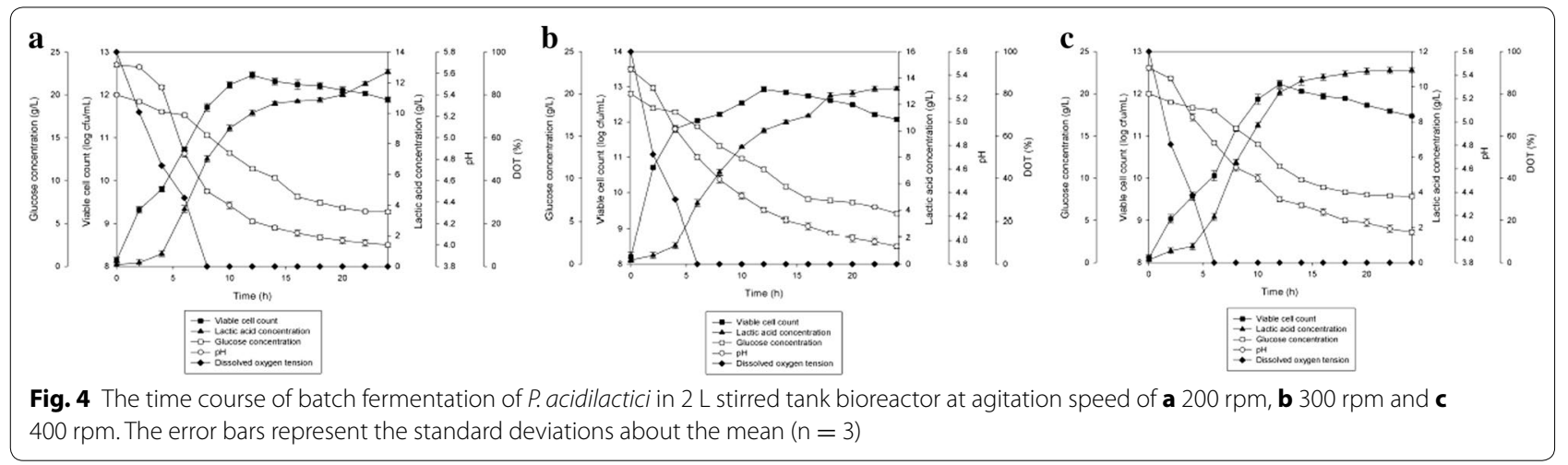

viable cell concentration, viable cell yield, viable cell productivity, lactic acid production, lactic acid yield and lactic acid productivity (Table 4). However, as the agitation speed was increased from 300 to $400 \mathrm{rpm}$, the cultivation performance of $P$. acidilactici was declined. Results from this study demonstrated that agitation speed had an influence on growth of $P$. acidilactici. Of all the three agitation speeds studied, $300 \mathrm{rpm}$ showed the highest maximum viable cell concentration $\left(1.8 \times 10^{12} \mathrm{cfu} / \mathrm{mL}\right)$ with improvement of 1.5 times and 1.8 times compared to 200 $\left(1.2 \times 10^{12} \mathrm{cfu} / \mathrm{mL}\right)$ and $400 \mathrm{rpm}\left(1.0 \times 10^{12} \mathrm{cfu} / \mathrm{mL}\right)$, respectively. This shows that agitation speed of $300 \mathrm{rpm}$ 
Table 4 Effect of agitation speed on growth of $P$. acidilactici in batch fermentation using $\mathbf{2} L$ stirred tank bioreactor

\begin{tabular}{|c|c|c|c|}
\hline \multirow[t]{2}{*}{ Kinetic parameter } & \multicolumn{3}{|c|}{ Agitation speed (rpm) } \\
\hline & 200 & 300 & 400 \\
\hline Maximum viable cell concentration (cfu/mL) & $1.2 \times 10^{12} \pm 0.17^{b}$ & $1.8 \times 10^{12} \pm 0.12^{\mathrm{a}}$ & $1.0 \times 10^{12} \pm 0.23^{c}$ \\
\hline Time to reach maximum viable cell concentration (h) & $12^{\mathrm{a}}$ & $12^{\mathrm{a}}$ & $12^{\mathrm{a}}$ \\
\hline Viable cell yield (cfu/g $\left.\mathrm{g}_{\text {Glucose }}\right)$ & $1.4 \times 10^{14} \pm 0.18^{b}$ & $2.0 \times 10^{14} \pm 0.1^{\mathrm{a}}$ & $1.2 \times 10^{14} \pm 0.17^{c}$ \\
\hline Viable cell productivity (cfu/mL h) & $9.9 \times 10^{10} \pm 0.16^{b}$ & $1.5 \times 10^{11} \pm 0.15^{\mathrm{a}}$ & $8.3 \times 10^{10} \pm 0.12^{c}$ \\
\hline Maximum lactic acid concentration ( $g / L)$ & $12.71 \pm 0.16^{\mathrm{b}}$ & $13.21 \pm 0.14^{\mathrm{a}}$ & $11.77 \pm 0.23^{c}$ \\
\hline Lactic acid yield (g/g $\mathrm{g}_{\text {Glucose) }}$ & $0.91 \pm 0.07^{\mathrm{a}}$ & $0.92 \pm 0.08^{\mathrm{a}}$ & $0.91 \pm 0.12^{\mathrm{a}}$ \\
\hline Lactic acid productivity (g/L h) & $0.53 \pm 0.08^{\mathrm{a}}$ & $0.54 \pm 0.08^{\mathrm{a}}$ & $0.48 \pm 0.1^{b}$ \\
\hline
\end{tabular}

The results presented are the average of triplicate experiments and are expressed as mean \pm standard deviation

$a, b, c$ Mean values in the same row with different superscripts are significantly different from each other $(P<0.05)$

provides suitable degree of mixing for growth of $P$. acidilactici compared to other agitation speeds.

Glucose consumption by $P$. acidilactici was found to be increased from $200(68.2 \%)$ to $300 \mathrm{rpm}(71 \%)$ and then reduced at $400 \mathrm{rpm}(63 \%)$. The highest viable cell yield was obtained at $300 \mathrm{rpm}\left(2.0 \times 10^{14} \mathrm{cfu} / \mathrm{g}_{\text {Glucose }}\right)$, followed by $200\left(1.4 \times 10^{14} \mathrm{cfu} / \mathrm{g}_{\text {Glucose }}\right)$ and $400 \mathrm{rpm}\left(1.2 \times 10^{14}\right.$ $\left.\mathrm{cfu} / \mathrm{g}_{\text {Glucose }}\right)$. This trend was similar to the viable cell productivity where $300 \mathrm{rpm}$ showed the highest viable cell productivity $\left(1.5 \times 10^{11} \mathrm{cfu} / \mathrm{mL} \mathrm{h}\right)$ compared to 200 $\left(9.9 \times 10^{10} \mathrm{cfu} / \mathrm{mL} \mathrm{h}\right)$ and $400 \mathrm{rpm}\left(8.3 \times 10^{10} \mathrm{cfu} / \mathrm{mL} \mathrm{h}\right)$. Maximum viable cell concentrations, viable cell yield and productivity obtained were significantly different $(P<0.05)$ at all of the three agitation speeds studied. The highest total lactic acid produced from the fermentation of $P$. acidilactici was found at $300 \mathrm{rpm}(13.21 \mathrm{~g} / \mathrm{L})$ followed by $200(12.71 \mathrm{~g} / \mathrm{L})$ and $400 \mathrm{rpm}(11.77 \mathrm{~g} / \mathrm{L})$, showing significant difference $(P<0.05)$ in lactic acid production for all of the agitation speeds studied. Nonetheless, lactic acid yield obtained were almost similar at all of the three agitation speeds, showing no significant difference $(P<0.05)$ for all of the cultures. As for the lactic acid productivity, cultures at 200 and $300 \mathrm{rpm}$ showed almost similar results with no significant difference $(P<0.05)$, whilst culture at $400 \mathrm{rpm}$ attained the lowest lactic acid productivity.

\section{Effect of feed rate in constant fed-batch fermentation} on growth of $P$. acidilactici using $\mathbf{2} \mathrm{L}$ stirred tank bioreactor Figure 5 depicted the time course of constant fed-batch fermentation of $P$. acidilactici in $2 \mathrm{~L}$ stirred tank bioreactor with different feeding rate of limiting substrate. As tabulated in Table 5, increased feeding rate from 0.008 to $0.015 \mathrm{~L} / \mathrm{h}$, showed 5.8 times improvement in maximum viable cell concentration from $1.9 \times 10^{12}$ to $1.1 \times 10^{13}$ $\mathrm{cfu} / \mathrm{mL}$. However, as the feeding rate was further increased from 0.015 to $0.03 \mathrm{~L} / \mathrm{h}$, maximum viable cell concentration obtained was reduced 6.9 times equivalent to $1.6 \times 10^{12} \mathrm{cfu} / \mathrm{mL}$. Maximum viable cell concentration obtained was significantly different $(P<0.05)$ at all of the three feeding rate.

The highest viable cell yield was obtained at $0.015 \mathrm{~L} / \mathrm{h}$ $\left(1.2 \times 10^{15} \mathrm{cfu} / \mathrm{g}_{\text {Glucose }}\right)$, followed by $0.008\left(2.1 \times 10^{14} \mathrm{cfu} /\right.$

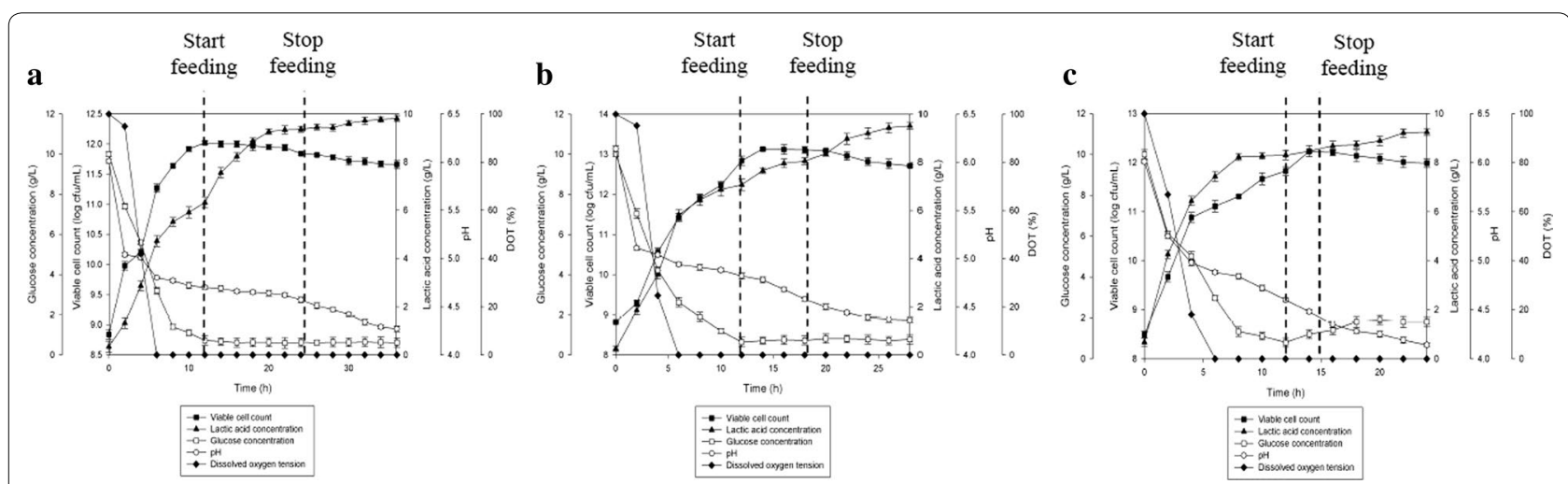

Fig. 5 The time course of constant fed-batch fermentation of P. acidilactici in $2 \mathrm{~L}$ stirred tank bioreactor at feeding rate of a $0.008 \mathrm{~L} / \mathrm{h}, \mathbf{b} 0.015 \mathrm{~L} / \mathrm{h}$ and $\mathbf{c} 0.03 \mathrm{~L} / \mathrm{h}$. The error bars represent the standard deviations about the mean $(n=3)$ 
Table 5 Effect of feeding rate on growth of $P$. acidilactici in constant fed-batch fermentation using $2 \mathrm{~L}$ stirred tank bioreactor

\begin{tabular}{|c|c|c|c|}
\hline \multirow[t]{2}{*}{ Kinetic parameter } & \multicolumn{3}{|l|}{ Feeding rate (L/h) } \\
\hline & 0.008 & 0.015 & 0.03 \\
\hline Maximum viable cell concentration (cfu/mL) & $1.9 \times 10^{12} \pm 0.21^{b}$ & $1.1 \times 10^{13} \pm 0.14^{\mathrm{a}}$ & $1.6 \times 10^{12} \pm 0.12^{c}$ \\
\hline Time to reach maximum viable cell concentration (h) & $12^{b}$ & $14^{\mathrm{a}}$ & $14^{\mathrm{a}}$ \\
\hline Viable cell yield (cfu/g $\left.\mathrm{g}_{\text {Glucose }}\right)$ & $2.1 \times 10^{14} \pm 0.16^{b}$ & $1.2 \times 10^{15} \pm 0.11^{\mathrm{a}}$ & $1.8 \times 10^{14} \pm 0.13^{c}$ \\
\hline Viable cell productivity (cfu/mL h) & $1.1 \times 10^{10} \pm 0.18^{c}$ & $7.9 \times 10^{11} \pm 0.12^{\mathrm{a}}$ & $1.1 \times 10^{11} \pm 0.17^{b}$ \\
\hline Maximum lactic acid concentration ( $\mathrm{g} / \mathrm{L}$ ) & $9.81 \pm 0.12^{\mathrm{a}}$ & $8.12 \pm 0.11^{c}$ & $9.25 \pm 0.14^{b}$ \\
\hline Lactic acid yield (g/g $\left./ \mathrm{g}_{\text {Glucose }}\right)$ & $1.09 \pm 0.08^{\mathrm{a}}$ & $0.89 \pm 0.06^{b}$ & $1.05 \pm 0.06^{\mathrm{a}}$ \\
\hline Lactic acid productivity (g/L h) & $0.26 \pm 0.11^{b}$ & $0.28 \pm 0.08^{b}$ & $0.36 \pm 0.07^{\mathrm{a}}$ \\
\hline
\end{tabular}

The results presented are the average of triplicate experiments and are expressed as mean \pm standard deviation

$a, b, c$ Mean values in the same row with different superscripts are significantly different from each other $(P<0.05)$

$\left.\mathrm{g}_{\text {Glucose }}\right)$ and $0.03 \mathrm{~L} / \mathrm{h}\left(1.8 \times 10^{14} \mathrm{cfu} / \mathrm{g}_{\text {Glucose }}\right)$. Whilst, the highest viable cell productivity was obtained at $0.015 \mathrm{~L} / \mathrm{h}$ $\left(7.9 \times 10^{11} \mathrm{cfu} / \mathrm{mL}\right.$ h) followed by $0.03\left(1.1 \times 10^{11} \mathrm{cfu} /\right.$ $\mathrm{mL} \mathrm{h})$ and $0.008 \mathrm{~L} / \mathrm{h}\left(1.1 \times 10^{10} \mathrm{cfu} / \mathrm{mL} \mathrm{h}\right)$. Viable cell yield and viable cell productivity obtained were significantly different $(P<0.05)$ at all of the three feeding rate studied.

As for the lactic acid production, the highest lactic acid produced from constant fed-batch fermentation of $P$. acidilactici was found at feeding rate $0.008 \mathrm{~L} / \mathrm{h}(9.81 \mathrm{~g} / \mathrm{L})$ followed by $0.03(9.25 \mathrm{~g} / \mathrm{L})$ and $0.015 \mathrm{~L} / \mathrm{h}(8.12 \mathrm{~g} / \mathrm{L})$. Nevertheless, lactic acid yield at feeding rate of 0.008 and $0.03 \mathrm{~L} / \mathrm{h}$ were almost similar (1.09 and $1.05 \mathrm{~g} / \mathrm{g}_{\text {Glucose }}$ respectively) with no significant difference $(P<0.05)$, whilst lactic acid yield at feeding rate of $0.015 \mathrm{~L} / \mathrm{h}$ was slightly lower $(0.89 \mathrm{~g} /$ $\left.\mathrm{g}_{\text {Glucose }}\right)$ showing significant difference $(P<0.05)$ for lactic acid yield at feeding rate of $0.015 \mathrm{~L} / \mathrm{h}$. As for the lactic acid productivity, culture with feeding rate of 0.008 and $0.015 \mathrm{~L} / \mathrm{h}$ showed almost similar results $(0.26$ and $0.28 \mathrm{~g} / \mathrm{L} \mathrm{h})$ with no significant difference $(P<0.05)$ at both feeding rate, whilst culture at $0.03 \mathrm{~L} / \mathrm{h}$ showed the highest lactic acid productivity. Improvement of 6.1 times in maximum viable cell concentration and reduction of 1.6 times in lactic acid production were achieved in constant fed-batch fermentation as compared to batch fermentation. There were significant differences $(P<0.05)$ in maximum viable cell concentration, viable cell yield, viable cell productivity, lactic acid production, yield and productivity obtained for both batch and fed-batch fermentations.

\section{Anion-exchange resin selectivity towards lactic acid}

Table 6 shows the sorption study of lactic acid, acetic acid, sodium acetate and glucose on IRA 67 resin when these components were present separately and in a pure form. From the sorption study and the amount of components adsorbed as calculated from Eq. 1, it was found that the adsorption of lactic acid on Amberlite IRA 67 resin was significantly different $(P<0.05)$ from the adsorption of acetic acid, sodium acetate and glucose. It was also found that the highest adsorbed component by IRA 67 resin was lactic acid, followed by acetic acid, sodium acetate and glucose.

\section{Constant fed-batch fermentation coupled with lactic acid extractive fermentation using anion-exchange resin}

Figure 6 shows the results for fed-batch fermentation coupled with extractive fermentation using IRA 67 anionexchange resin that was conducted at the best fermentation conditions as observed from the previous sections

Table 6 Selectivity of Amberlite IRA 67 resin (10 g/L) towards lactic acid, acetic acid, glucose and sodium acetate

\begin{tabular}{llll}
\hline Component & \multicolumn{3}{l}{ Adsorption } \\
\cline { 2 - 4 } & Initial concentration (g/L) & Equilibrium concentration (g/L) & Amount adsorbed (g/g) \\
\hline Lactic acid & 5 & $1.02 \pm 0.09$ & $0.40 \pm 0.10^{\mathrm{a}}$ \\
Acetic acid & 5 & $1.84 \pm 0.13$ & $0.32 \pm 0.11^{\mathrm{b}}$ \\
Sodium acetate & 5 & $2.96 \pm 0.08$ & $0.20 \pm 0.09^{\mathrm{c}}$ \\
Glucose & 5 & $3.23 \pm 0.12$ & $0.18 \pm 0.09^{\mathrm{c}}$ \\
\hline
\end{tabular}

The results of equilibrium concentration and amount adsorbed are the average of triplicate experiments

Statistically significant coefficient $(P<0.05)$ are expressed as mean $\pm S E$

$a, b, c$ Mean values with the different letters are significantly different 


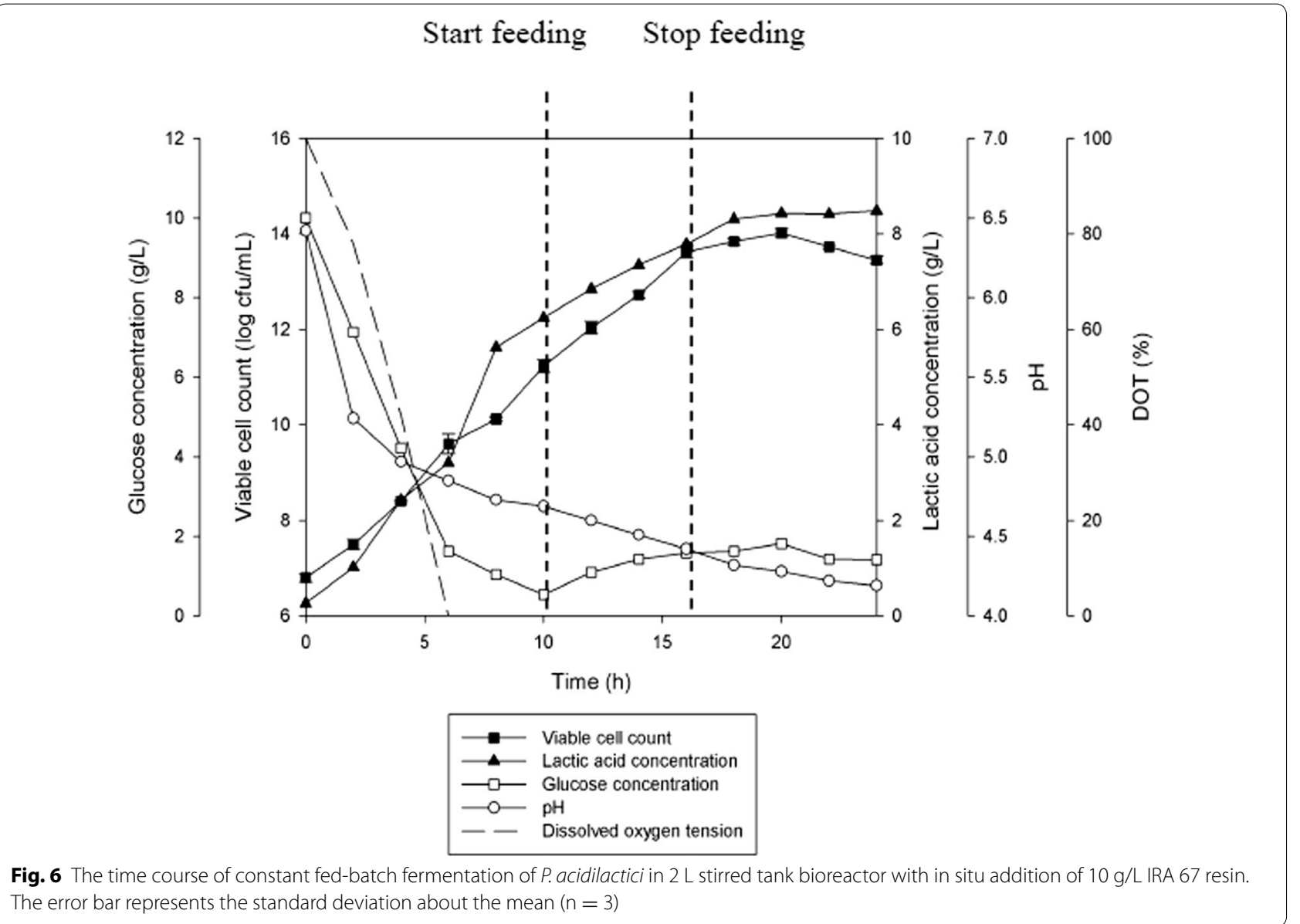

(glucose concentration of not more than $10 \mathrm{~g} / \mathrm{L}$, fermentation without $\mathrm{pH}$ control, fermentation with facultative condition, agitation speed of $300 \mathrm{rpm}$ and feeding rate of $0.015 \mathrm{~L} / \mathrm{h}$ ). As tabulated in Table 7, the growth of $P$. acidilactici with resin addition for fed-batch fermentation was found to be improved by 9.1 times $\left(1.0 \times 10^{14} \mathrm{cfu} / \mathrm{mL}\right)$ compared to the conventional fed-batch fermentation without resin addition $\left(1.1 \times 10^{13} \mathrm{cfu} / \mathrm{mL}\right)$. However, the time taken for the culture to reach maximum viable cell concentration was $6 \mathrm{~h}$ longer in the fed-batch fermentation with resin compared to without resin. Viable cell yield and viable cell productivity obtained in the culture

Table 7 Effect of resin addition on growth of $P$. acidilactici in fed-batch fermentation using $\mathbf{2} L$ stirred tank bioreactor

\begin{tabular}{lll}
\hline Kinetic parameter & Fed-batch without resin & Fed-batch with resin \\
\hline Maximum viable cell concentration (cfu/mL) & $1.1 \times 10^{13} \pm 0.14^{\mathrm{b}}$ & $1.0 \times 10^{14} \pm 0.07^{\mathrm{a}}$ \\
Time to reach maximum viable cell concentration (h) & $14^{\mathrm{b}}$ & $20^{\mathrm{a}}$ \\
Viable cell yield (cfu/g $\mathrm{g}_{\text {Glucose }}$ & $1.2 \times 10^{15} \pm 0.11^{\mathrm{b}}$ & $7.2 \times 10^{16} \pm 0.12^{\mathrm{a}}$ \\
Viable cell productivity (cfu/mL h) & $7.9 \times 10^{11} \pm 0.12^{\mathrm{b}}$ & $5.1 \times 10^{12} \pm 0.08^{\mathrm{a}}$ \\
Lactic acid accumulated (g/L) & $8.12 \pm 0.11^{\mathrm{b}}$ & $8.78 \pm 0.06^{\mathrm{a}}$ \\
Lactic acid produced (g/L) & $8.12 \pm 0.11^{\mathrm{b}}$ & $12.24 \pm 0.08^{\mathrm{a}}$ \\
Lactic acid yield (g/g $/$ lucose) & $0.89 \pm 0.06^{\mathrm{a}}$ & $0.72 \pm 0.06^{\mathrm{b}}$ \\
Lactic acid productivity (g/L h) & $0.28 \pm 0.08^{\mathrm{b}}$ & $0.43 \pm 0.04^{\mathrm{a}}$
\end{tabular}

The results presented are the average of triplicate experiments

Statistically significant coefficient $(P<0.05)$ are expressed as mean \pm SE

a,b Mean values with the different letters are significantly different 
with resin were 8.5 times and 8.6 times higher, respectively, than that obtained in the culture without resin. There were significant differences $(P<0.05)$ in maximum viable cell concentration, yield and productivity for both fed-batch fermentations with and without resin addition. Lactic acid accumulated in the culture was lower in the fed-batch fermentation with resin addition $(8.78 \mathrm{~g} / \mathrm{L})$ compared to fed-batch fermentation without resin addition $(9.62 \mathrm{~g} / \mathrm{L})$. However, the total lactic acid produced was higher in fed-batch fermentation with resin $(12.24 \mathrm{~g} / \mathrm{L})$ compared to fed-batch fermentation without resin $(9.62 \mathrm{~g} / \mathrm{L})$. On the other hand, lactic acid yield for fed-batch fermentation with resin was lower $\left(0.72 \mathrm{~g} / \mathrm{g}_{\mathrm{Glu}}\right.$ cose) than fed-batch fermentation without resin $(0.84 \mathrm{~g} /$ $\left.\mathrm{g}_{\text {Glucose }}\right)$ and lactic acid productivity was higher in the culture with resin $(0.43 \mathrm{~g} / \mathrm{L} \mathrm{h})$ compared to the culture without resin $(0.33 \mathrm{~g} / \mathrm{L} \mathrm{h})$. There were significant differences $(P<0.05)$ in lactic acid production, yield and productivity obtained for both fed-batch fermentations with and without resin addition.

\section{Discussion}

Reduced viable cell concentration with increased glucose concentration was due to high lactic acid accumulation in the culture since $P$. acidilactici undergo homofermentation. Generally, lactic acid conversion rate from sugar surpass $80 \%$ of the theoretical yield for homofermentative bacteria (Liu et al. 2013) and fermentation in lactobacilli tends to redirect its carbon flux from cell built-up to lactic acid production (Ming et al. 2016).

The results from the present study (Table 1) are similar to the findings of Monteagudo et al. (1997), who reported that there was an inhibition on bacterial growth by lactic acid when the lactic acid was rapidly being produced after the exponential phase of the growth. Reduced in final viable cell concentration of $P$. acidilactici was associated with high lactic acid concentration in the culture. This was due to the acidification of cytoplasm and failure of proton motive forces (Wee et al. 2006). The acidification of cytoplasm is causes by the undissociated lactic acid that passes through the bacterial membrane and dissociates inside the cell. The undissociated lactic acid is soluble within the cytoplasmic membrane whilst the dissociated lactate is insoluble. Eventually, this affects the transmembrane $\mathrm{pH}$ gradient and reduces the amount of energy that may be used for cell growth. Since lactic acid produced from fermentation causes acidification of medium and cytoplasm which inhibits the bacterial growth, therefore lactic acid produced in the culture must be either neutralized or removed as it is formed in order to maintain the $\mathrm{pH}$ within the optimal range ( $\mathrm{pH} 5-7$ ) (Nomura et al. 1987; Roberto et al. 2007).
The maximum viable cell concentration of $P$. acidilactici reduced when $\mathrm{NaOH}$ was added because the additional ions from $\mathrm{NaOH}$ increased the osmotic pressure of the medium, causing reduced cell growth (Cui et al. 2016). In addition, the accumulated lactic acid was not completely neutralized by $\mathrm{NaOH}$ because weak organic acids such as lactic acid and acetic acid are less dissociated in solution at any $\mathrm{pH}$ values compared to strong acids (Lund et al. 2014). Therefore, only part of the lactic acid was dissociated into lactate ions and the undissociated lactic acid which is membrane soluble will enter the cytoplasm via simple diffusion and dissociate inside the cell causing acidification of cytoplasm (Wee et al. 2006). In addition, the dissociated lactate ions can combine with external protons present and enter the cytoplasm in undissociated lactic acid form (Lund et al. 2014). The diffusion of lactic acid into the cytoplasm causes lactic acid to be rapidly dissociated releasing protons and anions within the cytoplasm (Broadbent et al. 2010). If the acidification of cytoplasm exceeds the buffering capacity of cytoplasmic and capabilities of efflux systems, the internal $\mathrm{pH}$ of the cell will drop and eventually causing failure in maintaining $\mathrm{pH}$ gradient and thus damage the cellular functions.

Facultative condition was shown to improve the cultivation performance of $P$. acidilactici compared to anaerobic condition, and the result is in agreement with the observation reported by Smetankova et al. (2012) where improved growth in the presence of oxygen was observed in cultivation of three wild strains of Lactobacillus plantarum compared to anaerobic condition. This was due to the lactate dehydrogenase (LDH) being used in conversion of pyruvate to lactate under anaerobic condition, reducing regeneration of coenzyme nicotinamide adenine dinucleotide $\left(\mathrm{NAD}^{+}\right)$by $\mathrm{LDH}$, where $\mathrm{NAD}^{+}$is needed in metabolism of sugar. Whereas, under facultative or aerobic conditions, instead of LDH, nicotinamide adenine dinucleotide (NADH) oxidases and NADH peroxidases are being used for regeneration of $\mathrm{NAD}^{+}$. This causing the microorganism to redirect the flux, producing more adenosine triphosphate (ATP) and thus, providing more energy for growth (Condon 1987). Oxygen is an important factor for survival and mortality of aerobic microorganism but not to the facultative anaerobe (Duwat et al. 2001). A few studies have revealed that under fermentation condition, oxygen was shown to contribute toxic effects on Lactococcus lactis by inhibiting its growth and survival (Duwat et al. 1995; Condon 1987). Prolonged aeration of lactococcal cultures can cause DNA alteration and cell death. Formation of hydroxyl radicals and hydrogen peroxide may be the cause of the oxygen toxicity (Anders et al. 1970). Therefore, in this study, oxygen was not supply throughout the fermentation, instead, oxygen was only supply at 
the beginning of the fermentation before inoculation until dissolved oxygen level reached $100 \%$ and then the aeration was stopped to create facultative condition for the fermentation to progress facultatively. Furthermore, $P$. acidilactici is categorized as facultative anaerobe (Papagianni and Anastasiadou 2009), hence, the influence of DOT or oxygen transfer rate contributed by agitation speed on growth of $P$. acidilactici may not be crucial.

As illustrated in Fig. 5b, it can be observed that glucose concentration was maintained at a very low level $(<1.0 \mathrm{~g} / \mathrm{L})$ during the fed-batch fermentation with constant feeding of glucose at $0.015 \mathrm{~L} / \mathrm{h}$ feeding rate. It can be concluded that the glucose consumption rate and the propagation of cells have achieved a quasi-steady state due to cell growth rate $(\mathrm{dX} / \mathrm{dt})=$ substrate consumption rate $(\mathrm{dS} / \mathrm{dt})=0$ for $6 \mathrm{~h}$. This situation happened when substrate added was utilized by the cells as it was added into the culture. When the glucose addition was stopped, the cells functioned as resting cells. However, lactic acid production was still continued until the culture reached death phase at approximately $22 \mathrm{~h}$ of fermentation. Although glucose concentration in the culture at feeding rate of $0.008 \mathrm{~L} / \mathrm{h}$ was similar to the culture at $0.015 \mathrm{~L} / \mathrm{h}$, however, maximum viable cells concentration obtained at constant feeding rate of $0.008 \mathrm{~L} / \mathrm{h}$ was significantly $(P<0.05)$ lower (Fig. 5a). This may be due to the slow feeding of glucose which restricted the growth or growth inhibition by lactic acid accumulated in the culture. These assumptions are supported by the declining in viable cell concentration as observed at approximately $20 \mathrm{~h}$ of fermentation although glucose was still being added into the culture. When high feeding rate $(0.03 \mathrm{~L} / \mathrm{h})$ was used, maximum viable cell concentration obtained was the lowest compared to other two feeding rate studied. It is tempting to speculate that fast addition of glucose at $0.03 \mathrm{~L} / \mathrm{h}$ feeding rate has contributed to cells dilution and thus reduced maximum viable cell concentration in the culture. This assumption is supported by the high glucose accumulation recorded as soon as the feeding rate was started and declined viable cell concentration observed at approximately $16 \mathrm{~h}$ of fermentation. This situation, in a way, indicated that glucose consumption by $P$. acidilactici was affected when glucose feeding rate exceeded both substrate consumption rate and cell growth rate, which in turn, inhibited the growth.

Based on the results obtained, application of fed-batch fermentation reduced the product inhibition caused by undissociated lactic acid accumulation in the culture. The improvement of cultivation performance of $P$. acidilactici in the constant fed-batch fermentation was achieved due to the suitable environment conditions created by this method, such as glucose concentration of below inhibitory level and low lactic acid production due to glucose metabolic flux towards cell growth instead of lactic acid production. Fed-batch fermentation has the advantage of reducing extended lag phase of low cell density in batch fermentation (Aguirre-Ezkauriatza et al. 2010). In addition, substrate exhaustion can also be assured in fed-batch fermentation. Often, the achievement of high biomass concentrations in fed-batch fermentation managed to partially overcome the strong inhibition effect of lactic acid. Results from this study showed that the application of fed-batch fermentation in cultivation of $P$. acidilactici has significantly reduced the accumulation of lactic acid in the culture with significant increased in the viable cell number. This finding is in agreement with the study conducted by Ming et al. (2016), who found that glucose metabolic flux towards cell growth was increased with a reduction in lactic acid production through fedbatch fermentation of Lactobacillus salivarius I 24. In past studies conducted, improvement of productivity and final yield of targeted product with shorter fermentation time in different fermentation media has been successfully achieved through the application of fedbatch fermentation (Lee et al. 2007). Approximately two times higher final cell concentration and beyond 100\% improvement in cell growth rate can be obtained by the application of fed-batch fermentation compared to batch fermentation. Besides, the application of fed-batch fermentation has also been widely applied in improving growth and biomass production of LAB such as in the production of Lactobacillus plantarum LP02 biomass isolated from infant feces with potential cholesterol lowering ability by Hwang et al. (2011) and improvement of cell mass production of Lactobacillus delbrueckii sp. bulgaricus WICC-B-02, a newly isolated probiotic strain from mother's milk by Elsayed et al. (2014).

Amberlite IRA 67 anion-exchange resin was selected as the candidate to explore fed-batch couple with extractive fermentation of lactic acid is mainly due to the capability of this resin to effectively adsorb lactic acid in lactic acid fermentation (Garret et al. 2015). Amberlite IRA 67 is based on a matrix of cross linked acrylic gel which is more hydrophilic than styrenic resins and their selectivity to most of organic acids is higher due to their matrix (Arup 1995). Although the presence of other components (acetic acid, sodium acetate and glucose) did interfere with the adsorption capacity of IRA 67 resin towards lactic acid, however the affinity of IRA 67 resin was higher towards lactic acid than the other components studied.

Fed-batch mode was found to be superior to the batch mode of fermentation for the growth of $P$. acidilactici. Hence, the fed-batch fermentation of $P$. acidilactici was further extended with the application of in situ lactic acid removal system. Lactic acid accumulated in the culture was lower in the fed-batch fermentation with resin addition compared to fed-batch fermentation without resin 
addition due to the adsorption of lactic acid by the resin. The results of this study clearly shown that the in situ addition of anion-exchange resin in the fed-batch fermentation significantly helped to enhance the growth of $P$. acidilactici by reducing the inhibitory effect of lactic acid.

\section{Abbreviations}

ATP: adenosine triphosphate; CFU: colony forming unit; DOT: dissolved oxygen tension; $\mathrm{HCl}$ : hydrochloric acid; LAB: lactic acid bacteria; $\mathrm{LDH}$ : lactate dehydrogenase; MRS: De Man Rogosa and Sharpe; NAD ${ }^{+}$: nicotinamide adenine dinucleotide; $\mathrm{NADH}$ : nicotinamide adenine dinucleotide; $\mathrm{NaOH}$ : sodium hydroxide; RP-HPLC: reverse-phase high performance liquid chromatography; rpm: rotation per minute; $v / v$ : volume per volume; vvm: volumetric air flow rate; w/v: weight/volume.

\section{Authors' contributions}

MO conducted the study, collected the data, analysed and interpreted the data, and wrote the manuscript. MH designed the study, analysed and interpreted the data, and revised the manuscript. ABA, HW and MRK guided the study design. All authors read and approved the final manuscript.

\section{Author details}

${ }^{1}$ Department of Bioprocess Technology, Faculty of Biotechnology and Biomolecular Sciences, Universiti Putra Malaysia, 43400 Serdang, Selangor, Malaysia. ${ }^{2}$ Bioprocessing and Biomanufacturing Research Center, Faculty of Biotechnology and Biomolecular Sciences, Universiti Putra Malaysia, 43400 Serdang, Selangor, Malaysia.

\section{Acknowledgements}

The authors are grateful and thank Universiti Putra Malaysia for the research facilities provided and the Ministry of Higher Education Malaysia for the Fundamental Research Grant Scheme (5524586) (FRGS/2/2014/SG05/UPM/02/7) funding throughout this research work.

\section{Competing interests}

The authors declare that they have no competing interests.

\section{Availability of data and materials}

All the data are presented in the main paper.

\section{Consent for publication}

Not applicable.

\section{Ethics approval and consent to participate}

Not applicable.

\section{Funding}

This study was funded by the Ministry of Higher Education Malaysia for the Fundamental Research Grant Scheme (5524586) (FRGS/2/2014/SG05/ UPM/02/7). The funding body has no role in the design of the study and collection, analysis, and interpretation of data and in writing the manuscript.

\section{Publisher's Note}

Springer Nature remains neutral with regard to jurisdictional claims in published maps and institutional affiliations.

Received: 28 September 2017 Accepted: 21 November 2017 Published online: 27 November 2017

\section{References}

Abdel-Rahman MA, Tashiro Y, Sonomoto K (2013) Recent advances in lactic acid production by microbial fermentation processes. Biotechnol Adv 31:877-902
Aguirre-Ezkauriatza EJ, Aguilar-Yáñez JM, Ramírez-Medrano A, Alvarez MM (2010) Production of probiotic biomass (Lactobacillus casei) in goat milk whey: comparison of batch, continuous and fed-batch cultures. Bioresour Technol 101:2837-2844

Anders RF, Hogg DM, Jago GR (1970) Formation of hydrogen peroxide by group N streptococci and its effect on their growth and metabolism. Appl Microbiol 19:608-612

Arup KS (1995) Sorption and desorption behavior of natural organic matter, ion exchange technology: advances in pollution control. Technomic Publishing Company, Lancaster, pp 149-189

Bai M, Wei Q, Yan ZH, Zhao XM, Li XG, Xu SM (2003) Fed-batch fermentation of Lactobacillus lactis for hyper-production of L-lactic acid. Biotechnol Lett 25:1833-1835

Boon BL, Heng JT, Eng SC (2007) Fed-batch fermentation of lactic acid bacteria to improve biomass production: a theoretical approach. J Appl Sci 7:2211-2215

Boonmee M, Cotano O, Amnuaypanich S, Grisadanurak N (2016) Improved lactic acid production by in situ removal of lactic acid during fermentation and a proposed scheme for its recovery. Arab J Sci Eng 41:2067-2075

Broadbent JR, Larsen RL, Deibel V, Steele JL (2010) Physiological and transcriptional response of Lactobacillus casei ATCC 334 to acid stress. J Bacteriol 192:2445-2458

Condon S (1987) Responses of lactic acid bacteria to oxygen. FEMS Microbiol Rev 46:269-280

Cui S, Zhao J, Zhang H, Chen W (2016) High-density culture of Lactobacillus plantarum coupled with a lactic acid removal system with anionexchange resins. Biochem Eng J 115:80-84

Duwat P, Ehrlich SD, Gruss A (1995) The recA gene of Lactococcus lactis: characterization and involvement in oxidative and thermal stress. Mol Microbiol 17:1121-1131

Duwat P, Sourice S, Cesselin B, Lambert G, Vido K, Gaudu P, Leloir Y, Violet F, Loubiere P, Gruss A (2001) Respiration capacity of the fermenting bacterium Lactococcus lactis and its positive effects on growth and survival. J Bacteriol 183:4509-4516

Elsayed EA, Othman NZ, Malek R, Tang T, Enshasy HE (2014) Improvement of cell mass production of Lactobacillus delbrueckii sp. bulgaricus WICC-B-02: a newly isolated probiotic strain from mother's milk. J Appl Pharm Sci 4:8-14

Gao Q, Liu F, Zhang T, Zhang J, Jia S, Yu C, Jiang K, Gao N (2010) The role of lactic acid adsorption by ion exchange chromatography. PLoS ONE 5(11):1-8

Garret BG, Srivinas K, Ahring BK (2015) Performance and stability of Amberlite ${ }^{\mathrm{TM}}$ IRA-67 ion exchange resin for product extraction and $\mathrm{pH}$ control during homolactic fermentation of corn stover sugars. Biochem Eng $94: 1-8$

Halim M, Mustafa NAM, Othman M, Wasoh H, Kapri MR, Ariff AB (2017) Effect of encapsulant and cryoprotectant on the viability of probiotic Pediococcus acidilactici ATCC 8042 during freeze-drying and exposure to high acidity, bile salts and heat. LWT Food Sc Technol 81:210-216

Hayek SA, Ibrahim SA (2013) Current limitations and challenges with lactic acid bacteria: a review. Food Nutr Sci 4:73-87

Hofvendahl K, Hahn-Hägerdal B (2000) Factors affecting the fermentative lactic acid production from renewable resources. Enzyme Microb Technol 26:87-107

Hujanen M, Linko S, Linko YY, Leisola M (2001) Optimisation of media and cultivation conditions for $\mathrm{L}(+)(\mathrm{S})$-lactic acid production by Lactobacillus casei NRRL B-441. Appl Microbiol Biotechnol 56:126-130

Hwang CF, Chen JN, Huang YT, Mao ZY (2011) Biomass production of Lactobacillus plantarum LP02 isolated from infant feces with potential cholesterol lowering ability. Afr J Biotechnol 10:7010-7020

Jianlong W, Ping L, Ding Z (1994) Extractive fermentation of lactic acid by immobilized, Lactobacillus casei using ion-exchange resin. Biotechnol Tech 8:905-908

Lee BB, Tham HJ, Chan ES (2007) Fed-batch fermentation of lactic acid bacteria to improve biomass production: a theoretical approach. J Appl Sci 7:2011-2215

Liu J, Wang Q, Zou H, Liu Y, Wang J, Gan K, Xiang J (2013) Glucose metabolic flux distribution of Lactobacillus amylophilus during lactic acid production using kitchen waste saccharified solution. Microb Biotechnol 6:685-693

Lund P, Tramonti A, Biase DD (2014) Coping with low pH: molecular strategies in neutralophilic bacteria. FEMS Microbiol Rev 38:1091-1125 
Ming LC, Halim M, Rahim RA, Wan HY, Ariff AB (2016) Strategies in fed-batch cultivation on the production performance of Lactobacillus salivarius I 24 viable cells. Food Sci Biotechnol 25:1393-1398

Monteagudo JM, Rodriguez L, Rincon J, Fuertes J (1997) Kinetics of lactic acid fermentation by Lactobacillus delbrueckii grown on beet molasses. J Chem Technol Biotechnol 68:271-276

Nomura Y, Iwahara M, Hongo M (1987) Lactic acid production by electrodialysis fermentation using immobilized growing cells. Biotechnol Bioeng 30:788-793

Papagianni M, Anastasiadou S (2009) Pediocins: the bacteriocins of Pediococci sources, production, properties and applications. Microb Cell Fact 8:1-16
Roberto I, Mussatto S, Mancilha I, Fernandes M (2007) The effects of pH and nutrient supplementation of brewer's spent grain cellulosic hydrolysate for lactic acid production by Lactobacillus delbrueckii. J Biotechnol 131:181-182

Smetankova J, Hladikova Z, Valach F, Zimanova M, Kohajdova Z, Greif G, Greifova M (2012) Influence of aerobic and anaerobic conditions on the growth and metabolism of selected strains of Lactobacillus plantarum. Acta Chimica Slovaca 5:204-210

Wee YJ, Kim JN, Ryu HW (2006) Biotechnological production of lactic acid and its recent applications. Food Technol Biotechnol 44:163-172

\section{Submit your manuscript to a SpringerOpen ${ }^{\circ}$ journal and benefit from:}

- Convenient online submission

- Rigorous peer review

- Open access: articles freely available online

- High visibility within the field

- Retaining the copyright to your article

Submit your next manuscript at springeropen.com 